\title{
Ю.А. Талалаенко
}

ГОО ВПО «Донецкий национальный медицинский университет имени М. Горького», Донецк

\section{КОМПЛЕКСНАЯ ПРОГРАММА СНИЖЕНИЯ РИСКОВ ПЕРИНАТАЛЬНЫХ ОСЛОЖНЕНИЙ У БЕРЕМЕННЫХ С ПИЕЛОНЕФРИТОМ}

Несмотря на значительные достижения современного акушерства по профилактике, диагностике и лечению пиелонефрита у беременных, большое количество научных работ, предлагающих множество методов терапии этого осложнения при беременности, данная проблема до сих пор остается актуальной. Пиелонефрит занимает одно из лидирующих мест среди патологии, которая осложняет течение беременности и возникает у 1-17 беременных из 100 [1-3]. Пиелонефрит у матери крайне неблагоприятно влияет на состояние внутриутробного плода и новорожденного. Риск развития акушерских и неонатальных осложнений при данном заболевании очень высок. По данным литературы любая инфекция мочевыводящих путей (ИМП) прежде всего связана с увеличением относительного риска (ОР) преждевременного прерывания беременности (ОР 1,6; 95\% доверительный интервал (ДИ) 1,4-1,8), рождения детей с низкой массой тела (ОР 1,4 ДИ 1,2-1,6) и недоношенностью (ОР 1,3 ДИ 1,1-1,4) [2, 3]. У новорожденных от матерей с пиелонефритом нарушена адаптация и заболеваемость в постнатальном периоде, что обуславливает повышение перинатальной смертности до 25-60 на 1000 родов и увеличение риска отставания в умственном развитии [4-6].

Целью выполненной работы являлось определение риска основных перинатальных осложнений при пиелонефрите, перенесенном в процессе гестации, создание комплексной программы ведения беременных с этой патологией, ее внедрение в практику и оценка эффективности этой программы.

\section{МАТЕРИАЛ И МЕТОДЫ}

Основываясь на результатах, проведенных нами ранее исследований, была создана комплексная программа ведения беременных с пиелонефритом и исследован риск перинатальных осложнений при ее использовании [7].

Ретроспективное рандомизированное исследование было проведено с вовлечением 245 историй родов беременных, перенесших в процессе гестации пиелонефрит (получивших стандартное лечение пиелонефрита в соответствии с клиническим протоколом) и 288 историй родов беременных без тяжелой акушерской и соматической патологии.

Также осуществлялось текущее несплошное наблюдение по признаку «пиелонефрит при беременности» с вовлечением 276 историй родов пациенток, у которых пиелонефрит был пролечен по разработанной программе. Расчет рисков выполнялся в пакете компьютерной лицензионной программы «MedStat» $[8,9]$. Оценивался абсолютный риск (АР) - отношение числа беременных, у которых возник определенный клинический исход (в данном случае возникновения перинатальных осложнений), в группах беременных к общему числу беременных в соответствующей группе. Кроме этого, анализировались изменения АР (разница рисков заболевания в группе пациентов, подверженных некоторому фактору, в данном случае пиелонефриту, и не подверженных ему). А также рассчитывался OP. ОР показал силу связи между пиелонефритом у матери и возникновением перинатальных осложнений [9].

\section{РЕЗУЛЬТАТЫ И ОБСУЖДЕНИЕ}

Нами была произведена оценка степени рисков некоторых перинатальных осложнений у беременных с пиелонефритом. Результаты исследования приведены в таблице 1 .

Как видно, при пиелонефрите, перенесенном в процессе гестации, происходит значительное повышение абсолютных рисков преждевременных родов, дистресса плода, а также риска рождения новорожденного с низкой массой тела и низким массо-ростовым коэффициентом $(\mathrm{p}<0,05)$. ОР преждевременных родов составляет 2,26 (ДИ 1,18-4,32), дистресса плода - ОР 2,82

(c) Ю.А. Талалаенко, 2019

(c) Университетская Клиника, 2019 
Оценка рисков некоторых перинатальных осложнений у беременных,

Таблица 1. перенесших пиелонефрит, и беременных низкого риска

\begin{tabular}{|c|c|c|c|c|}
\hline \multirow[b]{2}{*}{ Риски } & \multicolumn{4}{|c|}{ События (риск и ДИ) } \\
\hline & $\begin{array}{c}\text { Преждевре- } \\
\text { менные роды } \\
\end{array}$ & $\begin{array}{c}\text { Дистресс } \\
\text { плода } \\
\end{array}$ & $\begin{array}{c}\text { Рождение } \\
\text { маловесного } \\
\text { новорожденного } \\
\end{array}$ & $\begin{array}{c}\text { Рождение новорожден- } \\
\text { ного с низким массо-рос- } \\
\text { товым коэффициентом } \\
\end{array}$ \\
\hline $\begin{array}{l}\text { Абсолютный риск у беремен- } \\
\text { ных с пиелонефритом }\end{array}$ & $\begin{array}{c}10,2 \\
(6,7-14,3)\end{array}$ & $\begin{array}{c}9,8 \\
(6,4-13,8)\end{array}$ & $\begin{array}{c}7,8 \\
(4,7-11,4)\end{array}$ & $\begin{array}{c}15,5 \\
(11,3-20,3)\end{array}$ \\
\hline $\begin{array}{l}\text { Абсолютный риск у беремен- } \\
\text { ных без тяжелой соматической } \\
\text { и акушерской патологии }\end{array}$ & $\begin{array}{c}4,6^{*} \\
(2,4-7,2)\end{array}$ & $\begin{array}{c}3,5^{*} \\
(1,7-5,9)\end{array}$ & $\begin{array}{c}3,1^{*} \\
(1,4-5,4)\end{array}$ & $\begin{array}{c}8,0^{*} \\
(5,1-11,4)\end{array}$ \\
\hline $\begin{array}{l}\text { Повышение абсолютного рис- } \\
\text { ка }\end{array}$ & $\begin{array}{c}5,7 \\
(1,3-10,5)\end{array}$ & $\begin{array}{c}6,3 \\
(2,1-11,0)\end{array}$ & $\begin{array}{c}4,6 \\
(0,8-8,9)\end{array}$ & $\begin{array}{c}7,5 \\
(2,1-13,2)\end{array}$ \\
\hline Относительный риск & $\begin{array}{c}2,26 \\
(1,18-4,32)\end{array}$ & $\begin{array}{c}2,82 \\
(1,38-5,78)\end{array}$ & $\begin{array}{c}2,48 \\
(0,8-8,9)\end{array}$ & $\begin{array}{c}1,94 \\
(1,19-3,17)\end{array}$ \\
\hline
\end{tabular}

Примечание: * - риски событий статистически значимо отличаются $(\mathrm{p}<0,05)$.

(ДИ 1,38-5,78), рождения маловесного новорожденного - ОР 2,48 (ДИ 0,8-8,9), рождения новорожденного с низким массо-ростовым коэффициентом - ОР 1,94 (ДИ 1,19-3,17). Полученные результаты соответствуют данным, полученным из доказательных источников $[4,5,10,11]$. Однако, обращает на себя факт более значительного увеличения степени риска возникновения осложнений. По-видимому, это связанно с общим ухудшением основных показателей здоровья населения нашего региона, которое наблюдается в последние годы и связано с тяжелой социально-экономической ситуацией на Донбассе.

Вышеизложенное обосновало выработку новых способов и методов антенатальной охраны плода при пиелонефрите у беременных, что производилось на основании наших предыдущих исследований [7].

На этапе женской консультации (семейного врача) при первом пренатальном посещении необходимо выделение беременных, имеющих факторы риска возникновения инфекции почек в процессе гестации $[12,13]$. Это беременные с бессимптомной бактериурией (БСБ), циститом, нейрогенным мочевым пузырем и нарушенной иннервацией мочевого пузыря, сахарным диабетом и глюкозурией беременных, ИМП и хламидиозом в анамнезе, нефролитиазом и аномалиями мочевыводящего тракта, а также беременные низкого социально-экономического статуса, ВИЧ-инфицированные и наркоманки. При наличии вышеперечисленных факторов ОР симптомных ИМП путей составляет 5,3 (ДИ 2,6$11,0)[5,13]$.

Беременным группы риска мы рекомендовали бактериологическое исследование мочи 1 раз в месяц, антибиотикотерапию при выявле- нии БСБ и цистита, лечение урогенитальной инфекции, коррекцию микробиоценоза влагалища и кишечника, полную компенсацию сахарного диабета, позиционную терапию, санацию других очагов инфекции, витаминотерапию [7].

Учитывая доказанный факт почти 50\% устойчивости Escherichia coli к ампициллину, из препаратов, показанных для лечения бессимптомной бактериурии и цистита, предпочтение следует отдать цефалоспоринам, а также фосфомицину. Назначается цефалексин 0,25-0,5 г 3-4 раза в день, цефуроксим - 0,25 г 2 раза в день в течении 4-7 суток, а также фосфомицин - 3 г однократно за 2 часа до или после еды [2, 3].

При возникновении симптомов пиелонефрита показана госпитализация в течении 24 часов с обязательным ранним началом антибиотикотерапии $[14,15]$. В стационарных условиях проводится общеклиническое обследование, включающее общий анализ крови, общий анализ мочи, определение концентрации креатинина, мочевины, коагулограмму, простой мазок из влагалища, ультразвуковое исследование (УЗИ) и кардиотокография плода, допплеровское исследование плодово-плацентарного кровотока при необходимости [16].

Бактериологическое исследование мочи - золотой стандарт для обнаружения бактериурии и его нельзя заменить. Однако, приблизительно 30\% экземпляров мочи могут быть загрязнены, особенно если нарушается техника сбора анализов $[3,5]$. Бактериологический посев мочи выполняется скорее для верификации факта инфекции мочевых путей, чем для выбора тактики ведения пациентки. Еще один недостаток бактериологического исследования мочи состоит в том, что требуется 24-48 часов для получения результатов. Быстрые диагностические ис- 
пытания являются альтернативами бактериологическому исследованию мочи. Мы рекомендуем для определения возможного возбудителя, а также активности иммунного ответа организма матери определять уровень антител к липополисахаридам - эндотоксину грамотрицательных бактерий (АТ к ЛПС) [17]. При высоких уровнях АТ к ЛПС грамотрицательной флоры высоковероятно определение в качестве возбудителя энтеробактерий. При низких уровнях АТ к ЛПС грамотрицательной флоры вероятным возбудителем может быть $\beta$-гемолитический стрептококк ( $\beta$-ГС). $\beta$-ГС вызывают ИМП приблизительно у $5 \%$ беременных [3].

Для определения тяжести инфекционного процесса у матери и прогноза для плода рекомендовано определение, C3а компонента комплемента, количества С-реактивного белка (СРБ), прокальцитонина [7, 18].

Внутривенная антимикробная терапия должна быть начата эмпирически и продолжена в течении 48 часов безлихорадочного периода до разрешения симптомов заболевания. Клинические испытания достаточно детально изучили парентеральные антибиотики, включая цефазолин, цефтриаксон и комбинацию ампициллина или цефазолина с гентамицином. Различные виды лечения для симптоматических ИМП с назначеним вышеуказанных антибиотиков являются одинаково эффективными. Это заключение основано на равных результатах клинической и микробиологической излеченности, количестве рецидивов, преждевременных родов, преждевременных разрывов плодного пузыря, необходимости замены антибиотика, длительности гипертемии и длительности госпитализации, а также одинаковом количестве новорожденных, нуждающихся в интенсивной терапии $[2,3,5]$.

Исходя из вышеизложенного, для начала терапии пиелонефрита рекомендуются внутривенные формы цефалоспоринов, включая цефазолин (внутривенный, первое поколение) по 1-2 г через 6-8 часов и цефтриаксон (внутримышечный или внутривенный, третье поколение) по 1-2 г каждые 24 часа. Можно также использовать внутривенный цефуроксим 0,75-1,5 г каждые 8 часов. Терапия пероральными антибиотиками продолжается в течении последующих 1014 суток и может завершаться амбулаторно. Назначается цефалексин 0,5 г 3-4 раза в день, цефуроксим - 0,25 г 2 раза в день, фосфомицин 2 г в сутки.

Важным фактором дезинтоксикационной терапии и хорошего функционирования почки является адекватная внутривенная гидратация $[14,15]$.
При высокой активности инфекционного процесса в почках, подтвержденного уровнем СРБ, СЗа и другими иммунологическими критериями, а также признаках внутриутробного страдания плода дополнительно рекомендовано проведение сеансов озонотерапии с энтерособцией [19-21].

Лечебные эффекты, возникающие при внутривенном введении озонированного физиологическиго раствора, основаны на известных механизмах биологического действия озона. Высокий окислительный потенциал озона обеспечивает бактерицидный эффект в отношении важнейших видов грамположительных и грамотрицательных бактерий. А иммуномодулирующее действие озона основано на его способности активировать фагоцитоз за счет пероксидов и стимуляции выработки цитокинов лимфоцитами и моноцитами [19, 20, 22].

Желудочно-кишечный тракт и, в частности, кишечник совершает экскрецию и элиминацию эндогенных токсинов из организма беременной и относится к мощным системам биологической детоксикации организма. Поэтому проведение энтеросорбции в сочетании с медикаментозной диареей патогенетически оправдано при синдроме эндогенной интоксикации, который неизбежно возникает при пиелонефрите у беременных [19, 20, 23].

Озонотерапия производится путем внутривенных инфузий озонированного физиологического раствора при концентрации озона в газовой смеси 0,5-1,5 мг/л в количестве 7-10 процедур. Энтеросорбцию осуществляют любым кишечным сорбентом в течение 10 дней. Для повышения эффективности энтеросорбции дополнительно создают лечебную диарею путем перорального применения 30\% раствора магния сульфата в расчете 10 мл на 1 кг массы тела пациентки [19, 20].

Медицинский озон также назначается при подозрении на резистентность возбудителя, и с целью потенцирования действия антибиотика $[7,19,20]$.

При наличии лейкоцитоза во влагалище, патологической флоры, беременным женщинам дополнительно назначается его санация с обязательным применением пробиотиков вагинально и внутрь. Пробиотики также необходимы для поддержания нормальной микрофлоры во влагалище и профилактики кандидоза при длительном курсе антибактериальной терапии [24].

Если пиелонефрит сопровождается признаками угрозы преждевременных родов, беременной назначается токолиз и короткий курс профилактики респираторного дистресс-синдрома 
плода (РДС). Использование токолитических средств может задержать преждевременное родоразрешение, однако, при выборе типа токолитического средства и агрессивности терапии необходимо учитывать риск отека легких. Причинами слабой клинической реакции на проводимую терапию (в течении 24-72 часов) может быть мочекаменная болезнь, околопочечный абсцесс, аномалия мочевого тракта, бактериальная резистентность к антибиотикотерапии. В этом случае выполняется УЗИ почек и проводится смена антибиотика с учетом вида возбудителя. Однако, терапия должна потенциально содержать аминогликозид. Гентамицин назначается в ударной дозе 2 мг/кг, затем 1,7 мг/кг каждые 8 часов [2, 3].

По нашим данным, добавление к терапии пиелонефрита медицинского озона позволяет потенцировать действие антибиотика и в некоторых случаях избежать его неоправданной замены, а также исключить риск тератогенеза [7, $19,20]$.

При выписке из стационара оценивается динамика регресса воспалительного процесса по уровню СРБ после терапии, возможный риск развития перинатальных осложнений, составляются рекомендации для врача женской консультации $[7,21,25]$.

При подозрении на развитие сепсиса, повреждение легких, почечной недостаточности комплекс диагностических мероприятий должен состоять из всех общеклинических исследований, развернутой коагулограммы, иммунограммы, включающей АТ к ЛПС, СЗа компонент комплемента, СРБ, прокальцитонин, бактериологического исследования крови с определением чувствительности к антибиотикам, УЗИ плода и почек беременной. В этом случае показана консультация уролога и, при необходимости, хирургическая санация очага инфекции (чрескожная нефростомия, вскрытие абсцесса почки, нефрэктомия) [15]. Своевременно нужно решить вопрос о возможности пролонгации беременности.

2,7\% беременных (ДИ 1,4\%-4,7\%) повторно госпитализируются по поводу обострения инфекционного процесса в почках [2]. 20\% (ДИ 16,6\%-23,6\%) беременных, перенесших пиелонефрит, диагностируется БСБ в родах. У $42 \%$ (ДИ 35,7\%-49,1\%) наблюдался хотя бы один эпизод ИМП после беременности. У 29\% (ДИ 21,4\%$36,4 \%)$ возникает пиелонефрит при последующей беременности [3].

Всем беременным, которые перенесли пиелонефрит, необходимо ежемесячно проводить бактериологическое обследование мочи до родов для своевременного выявления рецидива. Для предотвращения повторной инфекции или рецидива этим беременным рекомендована хроническая терапия супрессии. С этой целью назначают нитрофураны повторяющимися курсами по 50- 100 мг ежедневно в течении 7-10 дней до 37 недели беременности (учитывая возрастающий в этом сроке риск гемолитической анемии у новорожденного из-за глютатионовой нестабильности эритроцита), а также в течении 4-6 недель после родов. Пероральный цефалексин 250 мг в отдельных случаях используется как посткоитальная профилактика наряду с непрерывной ежедневной супрессией нитрофуранами для предотвращения рецидива [7].

Клюквенный сок также показан в качестве средства, предотвращающего рецидивы пиелонефрита, и его применение сокращает риск раз-

Оценка рисков некоторых перинатальных осложнений у беременных,

Таблица 2. которые получили различные виды лечения пиелонефрита

\begin{tabular}{|c|c|c|c|c|}
\hline \multirow[b]{2}{*}{ Риски } & \multicolumn{4}{|c|}{ События (риск и 95\% доверительный интервал) } \\
\hline & $\begin{array}{c}\text { Преждевре- } \\
\text { менные роды }\end{array}$ & $\begin{array}{c}\text { Дистресс } \\
\text { плода } \\
\end{array}$ & $\begin{array}{c}\text { Рождение } \\
\text { маловесного } \\
\text { новорожденного } \\
\end{array}$ & $\begin{array}{c}\text { Рождение новорожден- } \\
\text { ного с низким массо-рос- } \\
\text { товым коэффициентом } \\
\end{array}$ \\
\hline $\begin{array}{l}\text { Абсолютный риск у беремен- } \\
\text { ных с пиелонефритом (стан- } \\
\text { дартное лечение) }\end{array}$ & $\begin{array}{c}10,2 \\
(6,7-14,3)\end{array}$ & $\begin{array}{c}9,8 \\
(6,4-13,8)\end{array}$ & $\begin{array}{c}7,8 \\
(4,7-11,4)\end{array}$ & $\begin{array}{c}15,5 \\
(11,3-20,3)\end{array}$ \\
\hline $\begin{array}{l}\text { Абсолютный риск у беремен- } \\
\text { ных с пиелонефритом (ком- } \\
\text { плексная программа) }\end{array}$ & $\begin{array}{c}4,7^{*} \\
(2,5-7,5)\end{array}$ & $\begin{array}{c}4,3 * \\
(2,3-7,1)\end{array}$ & $\begin{array}{c}2,5^{*} \\
(1,0-4,7)\end{array}$ & $\begin{array}{c}5,8 * \\
(3,4-8,9)\end{array}$ \\
\hline Снижение абсолютного риска & $\begin{array}{c}5,5 \\
(1,0-10,3)\end{array}$ & $\begin{array}{c}5,4 \\
(1,0-10,2)\end{array}$ & $\begin{array}{c}5,2 \\
(1,4-9,5)\end{array}$ & $\begin{array}{c}9,7 \\
(4,5-15,2)\end{array}$ \\
\hline Относительный риск & $\begin{array}{c}2,17 \\
(1,13-4,14)\end{array}$ & $\begin{array}{c}2,25 \\
(1,15-4,41)\end{array}$ & $\begin{array}{c}3,06 \\
(1,31-7,15)\end{array}$ & $\begin{array}{c}2,68 \\
(1,53-4,68)\end{array}$ \\
\hline
\end{tabular}

Примечание: * - риски событий статистически значимо отличаются $(\mathrm{p}<0,05)$. 
вития ИМП на 12-20\%. Доказано, что проантоцианидины в соке клюквы ингибируют адгезию уропатогенов к эпителию мочевого тракта, таким образом предотвращая развитие ИМП [26].

Хорошей альтернативой применению антибактериальных средств для профилактики обострения септического процесса в почках является озонотерапия $[7,19,20]$. Необходимо учитывать все доказанные эффекты озона, а также его позитивное влияние на внутриутробный плод.

Родоразрешение женщин, перенесших пиелонефрит, предпочтительно провести через естественные родовые пути. Учитывая наличие бактериурии в родах у $20 \%$ пациенток, необходимо в этот период провести бактериологический посев мочи.

Если в качестве возбудителя пиелонефрита изначально был определен $\beta$-ГС и таким образом подтверждена обсемененность беременной этим патогеном, для уменьшения риска инфекции новорожденных показана интранатальная антибиотикотерапия пенициллином или ампициллином $[2,13]$.

Если ожидается рождение маловесного новорожденного (срок гестации менее 34 нед.) и предварительно не проводился курс профилактики РДС плода клюкокортикоидами, назначается дексаметазон или бетаметазон по короткой схеме 24 мг. Необходимо заранее подготовиться к возможной реанимации и проведению интенсивной терапии новорожденному [27].

При подозрении на внутриутробную инфекцию, малом весе при рождении рекомендовано определение в крови пуповины маркеров воспаления, СЗа компонента комплемента, СРБ, прокальцитонина. Проводится бактериологическое исследование новорожденного [21, 27].

Женщинам с выявленной бактериурией в родах, а также с обострением пиелонефрита в родах и после родов проводится антибиотикотерапия в сочетании с озонотерапией.

В соответствии с вышеизложенной программой было проведено 276 беременных. Для подтверждения эффективности программы были оценены риски некоторых перинатальных осложнений, которые возникли у беременных (табл. 2.).

Отмечается статистически значимое снижение абсолютного риска (САР) преждевременных родов - 5,5 (ДИ 1,0-10,3), САР дистресса плода составило 5,4 (ДИ 1,0-10,2), САР рождения ма- ловесного новорожденного - 4,5 (ДИ 0,6-8,8), САР рождения новорожденного с низким массоростовым коэффициентом - 7,2 (ДИ 1,6-12,9) по сравнению с беременными, получившими традиционное лечение пиелонефрита $(\mathrm{p}<0,05)$.

Риск вышеперечисленных осложнений у беременных с пиелонефритом, получивших лечение по предложенной программе, статистически значимо не отличается от риска этих осложнений в группе беременных без тяжелой акушерской и соматической патологии $(p>0,05)$ (табл. 1.).

Риск преждевременных родов при ведении беременных по этой предложенной нами программе снижается в 2,17 раза (ДИ 1,13-4,14), дистресса плода - в 2,25 раза (ДИ $1,15-4,41$ ), рождения маловесного новорожденного - в 3,06 раза (ДИ 1,31-7,15), рождения новорожденного с низким массо-ростовым коэффициентом - в 2,68 раза (ДИ 1,53-4,68) по сравнению с беременными, которым лечат пиелонефрит по традиционной методике $(\mathrm{p}<0,05)$.

\section{В Ы В 0 д Ы}

Ведение беременных с риском возникновения пиелонефрита, а также пациенток, у которых возник пиелонефрит должно осуществляться планомерно и последовательно. Комплексная программа ведения беременных с пиелонефритом включает в себя выявление беременных группы риска возникновения пиелонефрита, определение антител к липополисахаридам - эндотоксинам грамотрицательных бактерий, СЗа компонента комплемента, C-реактивного белка и прокальцитонина, адекватную антибиотикотерапию в сочетании с озонотерапией с энтеросорбцией, оценку динамики регресса воспалительного процесса в почках по уровню C-реактивного белка и оценку риска развития перинатальных осложнений. При подозрении на внутриутробную инфекцию, малом весе при рождении рекомендовано определение в крови пуповины маркеров воспаления, С3а компонента комплемента, С-реактивного белка, прокальцитонина.

Внедрение комплексной программы ведения беременных с пиелонефритом позволяет значительно снизить риск основных перинатальных осложнений у этой категории больных, что оптимизирует исходы беременности и прогноз для детей, рожденных матерями с пиелонефритом. 


\section{Ю.А. Талалаенко}

ГОО ВПО «Донецкий национальный медицинский университет имени М. Горького», Донецк

\section{КОМПЛЕКСНАЯ ПРОГРАММА СНИЖЕНИЯ РИСКОВ ПЕРИНАТАЛЬНЫХ ОСЛОЖНЕНИЙ У БЕРЕМЕННЫХ С ПИЕЛОНЕФРИТОМ}

В результате исследования 533 историй родов было определено, что ОР преждевременных родов при пиелонефрите составляет 2,26 (95\% доверительный интервал (ДИ) 1,18-4,32), дистресса плода - ОР 2,82 (ДИ 1,38-5,78), рождения маловесного новорожденного - ОР 2,48 (ДИ 0,8-8,9), рождения новорожденного с низким массо-ростовым коэффициентом ОР 1,94 (ДИ 1,19-3,17).

Была разработана комплексная программа ведения беременных с пиелонефритом, по которой было проведено 276 беременных. Она включала в себя определение антител к липополисахаридам - эндотоксинам грамотрицательных бактерий, С3а компонента комплемента, С-реактивного белка и прокальцитонина, адекватную антибиотикотерапию в соче- тании с озонотерапией с энтеросорбцией, оценку динамики регресса воспалительного процесса в почках по уровню С-реактивного белка и оценку риска развития перинатальных осложнений. При подозрении на внутриутробную инфекцию, малом весе при рождении рекомендовано определение в крови пуповины маркеров воспаления, СЗа компонента комплемента, C-реактивного белка, прокальцитонина.

Риск преждевременных родов при ведении беременных по предложенной нами программе снижается в 2,17 раза (ДИ 1,13-4,14), дистресса плода - в 2,25 раза (ДИ 1,15-4,41), рождения маловесного новорожденного - в 3,06 раза (ДИ $1,31-7,15)$.

Ключевые слова: беременность, пиелонефрит, перинатальные осложнения.

\section{J.A. Talalayenko}

\section{SEI HPE «M. Gorky Donetsk National Medical University», Donetsk}

\section{THE COMPLEX PROGRAM FOR DECREASE OF THE PERINATAL COMPLICATIONS RISKS IN PREGNANT WOMEN WITH PYELONEPHRITIS}

After analysis of 533 labor and delivery medical records it has been determined, that the relative risks (RR) of preterm delivery, fetal distress and low birth weight in pyelonephritis are 2,26 (95\% confidence interval (CI) 1,18-4,32), 2,82 (CI 1,38-5,78) and 2,48 (CI 0,8$8,9)$, respectively.

The complex program of management of pregnant women with pyelonephritis was developed and implemented in 276 pregnant women. The program included assessment of antibodies to lipopolysaccharides (endotoxins of gram-negative bacterias), C3a component of complement, C-reactive protein and procalcitonin and treatment with adequate antibiotic therapy supplemented by ozonotherapy and enterosorption. The level of C-reactive protein at the end of treatment was as- sessed to confirm regression of inflammatory process in kidneys and to estimate probability of development of perinatal complications. Assessment of umbilical cord blood for C3a component of complement, C-reactive protein and procalcitonin was recommended in case of assumption of an intra-uterine infection and in low birth weight neonates.

The risk of preterm delivery, fetal distress and low birth weight in pregnant with pyelonephritis after implementation of this program decreased 2,17 (CI 1,13-4,14), 2,25 (CI 1,15-4,41) and 3,06 (CI 1,31-7,15) times respectively.

Key words: pregnancy, pyelonephritis, perinatal complications.

\section{ЛИТЕРАТУРА}

1. Климкин А., Фрейдин А., Петров С., Хурасева А. Хронический пиелонефрит беременных. Врач. 2017; 1: 2224.

2. Zanatta D.A.L., Rossini M.M., Trapani Júnior A. Pyelonephritis in Pregnancy: Clinical and Laboratorial Aspects and Perinatal Results. Rev. Bras. Ginecol. Obstet. 2017; 39 (12): 653-658. doi: 10.1055/s-0037-1608627.

3. Valent A.M., Peticca K., DiMatteo A., Banks S., Shah R., Chernicky L. et al. Pyelonephritis in Pregnancy: Prediction of Prolonged Hospitalization and Maternal Morbidity using Prognostic Scoring Systems. Am. J. Perinatol. 2017; 34 (12): 1212-1218. doi: 10.1055/s-0037-1602418.

4. Стяжкина С.Н., Черненкова М.Л., Набиуллина А.А., Низаметдинова Л.К. Острый гестационный пиелонефрит, этиопатогенетические аспекты, диагностика и лечение (обзорная статья). Проблемы современной науки и образования. 2015; 6 (36): 201-204.

5. Schneeberger C., Geerlings S.E., Middleton P., Crowther

\section{REFERENCES}

1. Klimkin A., Freidin A., Petrov S., Khuraseva A. Khronicheskii pielonefrit beremennykh. Vrach. 2017; 1: 22-24 (in Russian).

2. Zanatta D.A.L., Rossini M.M., Trapani Júnior A. Pyelonephritis in Pregnancy: Clinical and Laboratorial Aspects and Perinatal Results. Rev. Bras. Ginecol. Obstet. 2017; 39 (12): 653-658. doi: 10.1055/s-0037-1608627.

3. Valent A.M., Peticca K., DiMatteo A., Banks S., Shah R., Chernicky L. et al. Pyelonephritis in Pregnancy: Prediction of Prolonged Hospitalization and Maternal Morbidity using Prognostic Scoring Systems. Am. J. Perinatol. 2017; 34 (12): 1212-1218. doi: $10.1055 / \mathrm{s}-0037-1602418$.

4. Styazhkina S.N., Chernenkova M.L., Nabiullina A.A., Nizametdinova L.K. Ostryi gestatsionnyi pielonefrit, etiopatogeneticheskie aspekty, diagnostika i lechenie (obzornaya stat'ya). Problemy sovremennoi nauki i obrazovaniya. 2015; 6 (36): 201-204 (in Russian).

5. Schneeberger C., Geerlings S.E., Middleton P., Crowther 
C.A. Interventions for preventing recurrent urinary tract infection during pregnancy. Cochrane Database Syst. Rev. 2015; 26 (7): CD009279. doi: 10.1002/14651858.CD009279. pub3.

6. Matuszkiewicz-Rowińska J., Małyszko J., Wieliczko M. Urinary tract infections in pregnancy: old and new unresolved diagnostic and therapeutic problems. Arch Med Sci. 2015; 11: 67-77.

7. Талалаєнко Ю.О. Перинатальні ускладнення у вагітних 3 пієлонефритом (діагностика, патогенез, лікування, профілактика, прогнозування): дис. ... доктора мед. наук. Донецьк; 2007. 401.

8. Лапач С.Н., Чубенко А.В., Бабич П.Н. Основные принципы применения статистических методов в клинических испытаниях. Киев: МОРИОН; 2002. 160.

9. Лях Ю.Е., Гурьянов В.Г., Хоменко В.Н., Панченко О.А. Основы компьютерной биостатистики: анализ информации в биологии, медицине и фармации статистическим пакетом MedStat. Донецк: Издатель Папакица E.K.; 2006. 211.

10. Курбаналиев Х.Р., Чернецова Г.С. Пиелонефрит беременных. Современный взгляд на проблемы урогинекологов (обзор литературы). Вестник КРСУ. 2017; 17 (2): 33-36.

11. Dotters-Katz S.K., Heine R.P., Grotegut C.A. Medical and infectious complications associated with pyelonephritis among pregnant women at delivery. Infect. Dis. Obstet. Gynecol. 2013; 2013: 124102.

12. Glaser A. P., Schaeffer A.J. Urinary Tract Infection and Bacteriuria in Pregnancy. Urol. Clin. North. Am. 2015; 42 (4): 547-560.

13. Labi A.K., Yawson A.E., Ganyaglo G.Y., Newman M.J. Prevalence and Associated Risk Factors of Asymptomatic Bacteriuria in Ante-Natal Clients in a Large Teaching Hospital in Ghana. Ghana Med. J. 2015; 49 (3): 154-158.

14. Madan I., Than N.G., Romero R., Chaemsaithong P. The peripheral whole-blood transcriptome of acute pyelonephritis in human pregnancy. J. Perinat. Med. 2014; 42 (1): 31-53. doi:10.1515/jpm-2013-0085.

15. Kokrdová Z., Pařízek A., Koucký M., Pašková A., Boudová B. Septic shock in pregnancy on the basis of an acute pyelonephritis. Ceska Gynekol. Summer. 2016; 81 (4): 286288.

16. Хардиков А.В., Петров С.В., Лядвин А.Ю. Связь плацентарно-плодового кровотока с ядерным индексом интоксикации при неосложненном пиелонефрите у беременных. Медицина. 2016; 4: 40-44.

17. Прилуцкий А.С., Талалаенко Ю.А., Майлян Э.А., Сергиенко А.С. Уровень антител к эндотоксину у беременных женщин с пиелонефритом. Імунологія та алергологія. 2005; 3: 54-56.

18. Талалаенко Ю.А., Прилуцкий А.С., Майлян Э.А. Активность СЗа компонентта комплемента у беременных с инфекционным поражением почек. Імунологія та алергологія. 2005; $1: 10-11$.

19. Прилуцький ОС, Талалаєнко Ю.О. Деклараційний патент України на корисну модель № 14550; 2005.

20. Талалаєнко Ю.О., Чайка В.К. Деклараційний патент України на корисну модель № 14537; 2005.

21. Игнатенко Г.А., Талалаенко Ю.А., Прилуцкий А.С. Системный воспалительный ответ матери и плода при пиелонефрите у беременных. Университетская клиника. 2018; 3(28): 18-25.

22. Кытикова О.Ю., Гвозденко Т.А. Феномен множественности терапевтических эффектов озонотерапии. Новая наука: Проблемы и перспективы. 2015; 5-2: 62-65.

23. Торчинов А., Кузнецов В., Цахилова С., Остаева Л., Сарахова Д., Кравцова М. Эффективность включения энтеросорбентов в терапию эндогенной интоксикации при гестозе. Врач. 2013; 7: 69-71.

24. Мельников В.А., Целкович Л.С., Высоцких Т.С., Балтер Р.Б. Нарушения биоценоза влагалища при гестационном пиелонефрите и его восстановление с применением культуры аутолактобацилл. Современные проблемы науки и образования. 2016;2. URL: http://sci-
C.A. Interventions for preventing recurrent urinary tract infection during pregnancy. Cochrane Database Syst. Rev. 2015; 26 (7): CD009279. doi: 10.1002/14651858.CD009279. pub3.

6. Matuszkiewicz-Rowińska J., Małyszko J., Wieliczko M. Urinary tract infections in pregnancy: old and new unresolved diagnostic and therapeutic problems. Arch Med Sci. 2015; 11: 67-77.

7. Talalayenko Yu.O. Perinatal'ni uskladnennya u vagitnikh $\mathrm{z}$ piyelonefritom (diagnostika, patogenez, likuvannya, profilaktika, prognozuvannya): dis. ... doktora med.nauk. Donets'k; 2007. 401 (in Ukrainian).

8. Lapach S.N., Chubenko A.V., Babich P.N. Osnovnye printsipy primeneniya statisticheskikh metodov v klinicheskikh ispytaniyakh. Kiev: MORION; 2002. 160 (in Russian).

9. Lyakh Yu.E., Gur'yanov V.G., Khomenko V.N., Panchenko O.A. Osnovy komp'yuternoi biostatistiki: analiz informatsii v biologii, meditsine i farmatsii statisticheskim paketom MedStat. Donetsk: Izdatel' Papakitsa E.K.; 2006. 211 (in Russian).

10. Kurbanaliev Kh.R., Chernetsova G.S. Pielonefrit beremennykh. Sovremennyi vzglyad na problemy uroginekologov (obzor literatury). Vestnik KRSU. 2017; 17 (2): 33-36 (in Russian).

11. Dotters-Katz S.K., Heine R.P., Grotegut C.A. Medical and infectious complications associated with pyelonephritis among pregnant women at delivery. Infect. Dis. Obstet. Gynecol. 2013; 2013: 124102.

12. Glaser A. P., Schaeffer A.J. Urinary Tract Infection and Bacteriuria in Pregnancy. Urol. Clin. North. Am. 2015; 42 (4): 547-560.

13. Labi A.K., Yawson A.E., Ganyaglo G.Y., Newman M.J. Prevalence and Associated Risk Factors of Asymptomatic Bacteriuria in Ante-Natal Clients in a Large Teaching Hospital in Ghana. Ghana Med. J. 2015; 49 (3): 154-158.

14. Madan I., Than N.G., Romero R., Chaemsaithong R. The peripheral whole-blood transcriptome of acute pyelonephritis in human pregnancy. J. Perinat. Med. 2014; 42 (1): 31-53. doi:10.1515/jpm-2013-0085.

15. Kokrdová Z., Pařízek A., Koucký M., Pašková A., Boudová V. Septic shock in pregnancy on the basis of an acute pyelonephritis. Ceska Gynekol. Summer. 2016; 81 (4): 286288.

16. Khardikov A.V., Petrov S.V., Lyadvin A.Yu. Svyaz' platsentarno-plodovogo krovotoka s yadernym indeksom intoksikatsii pri neoslozhnennom pielonefrite u beremennykh. Meditsina. 2016; 4: 40-44 (in Russian).

17. Prilutskii A.S., Talalaenko Yu.A., Mailyan E.A., Sergienko A.S. Uroven' antitel k endotoksinu u beremennykh zhenshchin s pielonefritom. Imunologiya ta alergologiya. 2005; 3: 54-56 (in Russian).

18. Talalaenko Yu.A., Prilutskii A.S., Mailyan E.A. Aktivnost' S3a komponentta komplementa u beremennykh $\mathrm{s}$ infektsionnym porazheniem pochek. Imunologiya ta alergologiya. 2005; 1: 10-11 (in Russian).

19. Priluts'kii OS, Talala€nko Yu.O. Deklaratsiinii patent Ukraïni na korisnu model' № 14550; 2005.

20. Talala€nko Yu.O., Chaika V.K. Deklaratsiinii patent Ukraïni na korisnu model' № 14537; 2005 (in Ukrainian).

21. Ignatenko G.A., Talalaenko Yu.A., Prilutskii A.S. Sistemnyi vospalitel'nyi otvet materi i ploda pri pielonefrite $\mathrm{u}$ beremennykh. Universitetskaya klinika. 2018; 3(28): 18-25 (in Russian).

22. Kytikova O.Yu., Gvozdenko T.A. Fenomen mnozhestvennosti terapevticheskikh effektov ozonoterapii. Novaya nauka: Problemy i perspektivy. 2015; 5-2: 62-65 (in Russian).

23. Torchinov A., Kuznetsov V., Tsakhilova S., Ostaeva L., Sarakhova D., Kravtsova M. Effektivnost' vklyucheniya enterosorbentov $\mathrm{v}$ terapiyu endogennoi intoksikatsii pri gestoze. Vrach. 2013; 7: 69-71 (in Russian).

24. Mel'nikov V.A., Tselkovich L.S., Vysotskikh T.S., Balter R.B. Narusheniya biotsenoza vlagalishcha pri gestatsionnom pielonefrite i ego vosstanovlenie s primeneniem kul'tury autolaktobatsill. Sovremennye problemy nauki i obrazovaniya. 2016; 2. URL: http://science-edu- 
ence-education.ru/ru/article/view?id=24283 (дата обращения: 18.05.2018).

25. Михайлова О.В., Ионов О.В., Антонов А.Г., Никитина И.В., Дегтярёва А.В., Левадная А.В., и др. Диагностическая ценность прокальцитонина и С-реактивного белка при врожденных инфекциях у детей с экстремально низкой и очень низкой массой тела при рождении. Педиатрическая фармакология. 2015; 12 (4): 422-428.

26. Mannucci C., Dante G., Miroddi M., Facchinetti F., D'Anna R., Santamaria A. et al. Vigilance on use of drugs, herbal products, and food supplements during pregnancy: focus on fosfomycin. J. Matern. Fetal. Neonatal. Med. 2017; 17: 1-4. doi: 10.1080/14767058.2017.1373761.

27. Талалаенко Ю.О., Юлиш Е.И., Талалаенко А.К. Пієлонефрит, плацента і новонароджений. Медикосоциальные проблемы семьи. 2014; 19 (1): 98-103. cation.ru/ru/article/view?id=24283 (data obrashcheniya: 18.05.2018) (in Russian).

25. Mikhailova O.V., Ionov O.V., Antonov A.G., Nikitina I.V., Degtyareva A.V., Levadnaya A.V., i dr. Diagnosticheskaya tsennost' prokal'tsitonina i S-reaktivnogo belka pri vrozhdennykh infektsiyakh $\mathrm{u}$ detei s ekstremal'no nizkoi ochen' nizkoi massoi tela pri rozhdenii. Pediatricheskaya farmakologiya. 2015; 12 (4): 422-428 (in Russian).

26. Mannucci C., Dante G., Miroddi M., Facchinetti F., D'Anna R., Santamaria A. et al. Vigilance on use of drugs, herbal products, and food supplements during pregnancy: focus on fosfomycin. J. Matern. Fetal. Neonatal. Med. 2017; 17: 1-4. doi: $10.1080 / 14767058.2017 .1373761$.

27. Talalaenko Yu.O., Yulish E.I., Talalaenko A.K. Piyelonefrit, platsenta i novonarodzhenii. Mediko-sotsial'nye problemy sem'i. 2014; 19 (1): 98-103 (in Ukrainian). 